\title{
PENGGUNAAN BAHAN DASAR PISANG AMBON (Musa acuminata) SEBAGAI MEDIA ALTERNATIF UNTUK PERTUMBUHAN JAMUR Aspergillus niger
}

\author{
Aida Wildatun Muthmainnah ${ }^{1}$, Lalu Srigede ${ }^{2}$, Yunan Jiwintarum ${ }^{3}$ \\ ${ }^{1-3}$ Jurusan Analis Kesehatan, Poltekkes Kemenkes Mataram, Indonesia
}

Article Info

Article history:

Received Jan $12^{\text {th }}, 2019$

Revised Mei $20^{\text {th }}, 2019$

Accepted Mei 26 $6^{\text {th }}, 2019$

Keyword:

Banana Ambon, Aspergillus niger

\begin{abstract}
Fungus is a microorganism that does not have chlorophyll so that in meeting its food needs is very dependent from the outside, a good growth medium is meia which contains all the nutrients needed by the organism to be grown one of which is carbohydrates, the source of carbohydrates in this study was obtained from ambon banana flour. The study observed the growth of Aspergillus niger mushrooms on alternative media made from ambon banana with a concentration of $10 \%$ and a concentration of $20 \%$ macroscopically and microscopically. Research Method: This research was descriptive in this research took place using purposive sampling method, Aspergillus niger mushrooms were isolated from food ingredients and grown on PDA (potato Dextrose Agar) media and alternative media of ambon banana (musa acuminata) were observed for 5 days by looking at the color, measured the diameter of the colony and the shape of the colony. The results of the study: $10 \%$ concentration and $20 \%$ concentration of colonies grow well in see macroscopically and microscopically. Conclusions: ambon banana powder can be used as an alternative medium for the growth of the fungus Aspergillus niger.

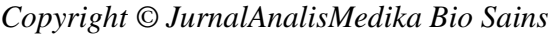
All rights reserved.
\end{abstract}

\begin{abstract}
ABSTRAK
Jamur adalah mikroorganisme yang tidak berklorofil sehingga dalam memenuhi kebutuhan pangannya sangat bergantung dari luar, media pertumbuhan yang baik adalah meia yang mengandung semua nutrien yang diperlukan oleh organisme yang akan ditumbuhkan salah satunya adalah karbohidrat, sumber karbohidrat dalam penelitian ini diperoleh dari tepung pisang ambon.Tujuan Penelitian mengamati pertumbuhan jamur Aspergillus niger pada media alternatif berbahan dasar pisang ambon dengan konsentrasi $10 \%$ dan konsentrasi 20\% secara makroskopis dan mikroskopis.Metode Penelitian: penelitian ini bersifat deskriptif penelitian ini berlangsung menggunakan metode purposive sampling, jamur Aspergillus niger diisolasi dari bahan pangan dan ditumbuhkan pada media PDA ( potato Dextrose Agar ) dan media alternatif pisang ambon ( musa acuminata) di amati selama 5 hari dengan melihat warna,diukur diameter koloni dan bentuk koloninya.Hasil penelitian: konsentrasi $10 \%$ dan konsentrasi $20 \%$ koloni tumbuh dengan baik dilihat secara makroskopis dan mikroskopis. Kesimpulan: bubuk pisang ambon dapat digunakan sebagai media alternatif untuk pertumbuhan jamur Aspergillus niger.
\end{abstract}

Kata kunci : pisang ambon,Aspergillus niger 
Mn, Mg, dan Fe, vit amin, air, dan energi (Cappucino, 2014). Salah satu jenis jamur yang bisa menyebabkan penyakit yaitu jamur Aspergillus niger. Aspergillus niger adalah jenis jamur yang sporanya terdapat pada kotoran burung dan kelelawar Spora ini dapat memasuki parenkim paru-paru bila terhirup dan menimbulkan Aspergillosis paru-paru. Penyakit tersebut bersifat primer bila tidak ada infeksi lain dan bila terjadi infeksi massal dengan spora, dalam hal ini sering berhubungan dengan pekerjaan penderita. (Anonymous, 2013).

Media Potato Dextrose Agar (PDA) adalah media yang umum untuk pertumbuhan jamur di laboratorium karena memiliki $\mathrm{pH}$ yang rendah $(\mathrm{pH} 4,5$ sampai 5,6) sehingga menghambat pertumbuhan bakteri yang membutuhkan lingkungan yang netral dengan $\mathrm{pH} 7,0$, dan suhu optimum.untuk pertumbuhan antara $25-30{ }^{\circ} \mathrm{C}$ (Cappucino, 2014).

Mahalnya media PDA instan yang mencapai ratusan ribu bahkan mencapai jutaan rupiah per setiap gramnya, serta melimpahnya sumber alam yang dapat digunakan sebagai media pertumbuhan mikroorganisme, mendorong peneliti untuk menemukan bahan-bahan yang mudah didapat serta murah dengan begitu dapat mengurangi keseluruhan biaya harus digunakan dalam penelitian.

Beberapa peneliti berhasil menemukan media alternatif pertumbuhan jamur dari sumber protein yaitu kacang hijau dan kacang kedelai hitam (Ravimannan et al, 2014). Selain penelitian dengan sumber protein, berbagai sumber karbohidrat juga berhasil digunakan sebagai media alternatif seperti pati singkong (Kwoseh et al, 2012),sagu dan uwi (Tharmila et al, 2011), kentang dan umbi palmirah (Ma rtyniuk et al, 2011).

Salah satu sumber karbohidrat lain yang mudah ditemukan dan belum banyak dimanfaatkan adalah pisang. Pisang (Musa paradisiaca) merupakan salah satu jenis buah yang mempunyai potensi cukup tinggi untuk dikelola. Buah pisang sendiri merupakan buah dengan sumber gizi yang lengkap karena mengandung nutrisi seperti air, gula, protein, lemak, vitamin, dan mineral. selain itu juga pisang mengandung asam tanin,fosfor,zat besi,zeng,magnesium dan pati.

Pati dapat dihidrolisis menjadi gula sederhana oleh mikroorganisme khususnya jamur. karena gula sederhana merupakan sumber nutrisi utama bagi mikroorganisme tersebut. Aspergillus niger merupakan mikroorganisme eukariot, saat ini diakui sebagai salah satu diantara beberapa makhluk hidup yang memiliki daerah penyebaran paling luas serta berlimpah di alam, selain itu jenis kapang ini juga merupakan kontaminan umum pada berbagai substrat di daerah tropis maupun subtropis (Adriani, 2005). Maka dari itu peneliti mencoba bahan dasar pisang ambon (Musa acuminata) sebagai media alternatif untuk pertumbuhan jamur Aspergillus niger.

\section{MetodePenelitian}

Penelitian ini merupakan penelitian bersifat "Deskriptif" yang dilakukan dilaboratorium untuk memberikan gambaran tentang suatu keadaan secara objektif terhadap sampel ( Notoamojo,2012 ). Tujuan dari penelitian ini adalah ingin mengetahui penggunaan pisang ambon sebagai media alternatif perrtumbuhan jamur Aspergillus niger dengan menggunakan 2 perlakuan yaitu :

T0 = Media PDA sebagai kontrol positif pertumbuhan

T1 = Penambahan tepung pisang ambon (Musa acuminata) dengan konsentrasi $10 \%$ dalam komposisi media alternatif

T2 = Penambahan tepung pisang ambon (Musa acuminata) dengan konsentrasi $20 \%$ dalam komposisi media alternatif

Tehknik pengambilan sampel dilakukan dengan teknik Purposive Sampling yaitu pengambilan sampel didasarkan pada suatu pertimbangan yang dibuat oleh peneliti sendiri (Notoatmodjo, 2012)

\section{Hasil Penelitian}

Penelitian ini dilakukan di slaboratorium Mikrobiologi Poltekes Kemenkes Mataram. Penelitian dilakukan dengan menggunakan pisang ambon sebagai media alternatif pertumbuhan jamur Aspergillus niger dengan masing-masing konsentrasi 10\% dan konsentrasi 20\%. Penelitian ini dilakukan sebanyak 8 kali pengulangan pada masing-masing-masing konsentrasi. Adapun hasil pemeriksaan media alternatif pisang ambon konsentrasi $10 \%$ dan konsenmtrasi $20 \%$ dapat dilihat pada tabel 4.1 dan 4.2. 
Tabel 4.1 Hasil pemeriksaan media alternatif pisang ambon dengan konsentrasi $10 \%$

\begin{tabular}{|c|c|c|c|c|c|c|}
\hline \multirow[t]{3}{*}{ Nama Media } & \multirow[t]{3}{*}{ Hari } & \multicolumn{5}{|c|}{ Aspergillus niger } \\
\hline & & \multicolumn{3}{|c|}{ Makroskopis } & \multicolumn{2}{|c|}{ Mikroskopis } \\
\hline & & Warna koloni & Ukuran & Bentuk & Warna & Bentuk \\
\hline $\begin{array}{l}\text { Media pisang ambon } \\
\text { konsentrasi } 10 \%\end{array}$ & 1 & Hitam & $0,3 \mathrm{~mm}$ & Bulat & Biru & Bulat tebal \\
\hline Media PDA & & Hitam & $0,5 \mathrm{~mm}$ & Bulat & Biru & Bulat tebal \\
\hline $\begin{array}{l}\text { Media pisang ambon } \\
\text { konsentrasi } 10 \%\end{array}$ & 2 & Hitam & $10 \mathrm{~mm}$ & Bulat & Biru & Bulat tebal \\
\hline Media PDA & & Hitam & $10 \mathrm{~mm}$ & Bulat & Biru & Bulat tebal \\
\hline $\begin{array}{l}\text { Media pisang ambon } \\
\text { konsentrasi } 10 \%\end{array}$ & 3 & Hitam & $10 \mathrm{~mm}$ & Bulat & Biru & Bulat tebal \\
\hline Media PDA & & Hitam & $19 \mathrm{~mm}$ & Bulat & Biru & Bulat tebal \\
\hline $\begin{array}{l}\text { Media pisang ambon } \\
\text { konsentrasi } 10 \%\end{array}$ & 4 & Hitam & $12 \mathrm{~mm}$ & Bulat & Biru & Bulat tebal \\
\hline Media PDA & & Hitam & $20 \mathrm{~mm}$ & Bulat & Biru & Bulat tebal \\
\hline $\begin{array}{l}\text { Media pisang ambon } \\
\text { konsentrasi } 10 \%\end{array}$ & 5 & Hitam & $12 \mathrm{~mm}$ & Bulat & Biru & Bulat tebal \\
\hline Media PDA & & Hitam & $23 \mathrm{~mm}$ & Bulat & Biru & Bulat tebal \\
\hline
\end{tabular}

Tabel 4.1 menunjukkan bahwa hasil penelitian yang telah dilakukan pada media alternatif pisang ambon (musa acuminata) pertumbuhan jamur Aspergilus niger menunjukan hasil yaitu pada pemeriksaan makroskopis berwarna hitam, ukuran diameter tertinggi $12 \mathrm{~mm}$ dan bentuknya bulat sedangkan pada pemeriksaan mikroskopis warnanya biru dan berbentuk bulat tebal.

Tabel 4.2 Hasil pemeriksaan media alternatif pisang ambon dengan konsentrasi $20 \%$

\begin{tabular}{|c|c|c|c|c|c|c|}
\hline \multirow[t]{3}{*}{ Nama Media } & \multirow[t]{3}{*}{ Hari } & \multicolumn{5}{|c|}{ Aspergillus niger } \\
\hline & & \multicolumn{3}{|c|}{ Makroskopis } & \multicolumn{2}{|c|}{ Mikroskopis } \\
\hline & & $\begin{array}{l}\text { Warna } \\
\text { koloni }\end{array}$ & Ukuran & Bentuk & Warna & Bentuk \\
\hline $\begin{array}{l}\text { Media pisang ambon } \\
\text { konsentrasi } 20 \%\end{array}$ & 1 & Hitam & $0,4 \mathrm{~mm}$ & Bulat & Biru & Bulat tebal \\
\hline Media PDA & & Hitam & $0,5 \mathrm{~mm}$ & Bulat & Biru & Bulat tebal \\
\hline $\begin{array}{l}\text { Media pisang ambon } \\
\text { konsentrasi } 20 \%\end{array}$ & 2 & Hitam & $13 \mathrm{~mm}$ & Bulat & Biru & Bulat tebal \\
\hline Media PDA & & Hitam & $10 \mathrm{~mm}$ & Bulat & Biru & Bulat tebal \\
\hline $\begin{array}{l}\text { sMedia pisang ambon } \\
\text { konsentrasi } 20 \%\end{array}$ & 3 & Hitam & $21 \mathrm{~mm}$ & Bulat & Biru & Bulat tebal \\
\hline Media PDA & & Hitam & $19 \mathrm{~mm}$ & Bulat & Biru & Bulat tebal \\
\hline $\begin{array}{l}\text { Media pisang ambon } \\
\text { konsentrasi } 20 \%\end{array}$ & 4 & Hitam & $21 \mathrm{~mm}$ & Bulat & Biru & Bulat tebal \\
\hline
\end{tabular}


ISSN: 2656-2456 (Online)

ISSN: 2356-4075 (Print)

\begin{tabular}{|l|l|l|l|l|l|l|}
\hline Media PDA & & Hitam & $20 \mathrm{~mm}$ & Bulat & Biru & Bulat tebal \\
\hline $\begin{array}{l}\text { Media pisang ambon } \\
\text { konsentrasi 20\% }\end{array}$ & 5 & Hitam & $25 \mathrm{~mm}$ & Bulat & Biru & Bulat tebal \\
\cline { 1 - 5 } Media PDA & & Hitam & $23 \mathrm{~mm}$ & Bulat & Biru & Bulat tebal \\
\hline
\end{tabular}

Tabel 4.2 menunjukkan bahwa hasil penelitian yang telah dilakukan pada media alternatif pisang ambon (musa acuminata) pertumbuhan jamur Aspergilus niger menunjukan hasil yaitu pada pemeriksaan makroskopis berwarna hitam, ukuran diameter tertinggi $25 \mathrm{~mm}$ dan bentuknya bulat sedangkan pada pemeriksaan mikroskopis warnanya biru dan berbentuk bulat tebal.

\section{Pembahasan}

Penelitian dilakukan dengan menggunakan media alternatif berbahan dasar pisang ambon ( musa acuminata) dengan konsentrasi 10\% dan konsentrasi 20\% dimana media PDA dijadikan sebagai media kontrol untuk pertumbuhan jamur Aspergillus niger. Pertumbuhan jamur Aspergillus niger di tandai dengan adanya perkembangan diameter, kesuburan spora dan warna miseliumnya. Media PDA memiliki pertumbuhan jamur Aspergillus niger terbaik, kemudian media alternatif pisang ambon dengan konsentrasi $20 \%$ dan terakhir media alternatif pisang ambon dengan konsentrasi $10 \%$. Hal ini sangat berkaitan dengan nutrisi yang terkandung dalam masing-masing perlakuan terutama kadar karbohidrat karena karbohidrat merupakan substrat utama untuk pertumbuhan jamur.

Media PDA sumber karbohidrat utamanya adalah kentang. Kentang dalam 100gr memiliki komponen karbohidrat yang tinggi yaitu 19,10 gr, sedangkan pada media alternatif sumber karbohidratnya berasal dari tepung pisang ambon (musa acuminata), dalam 100 gr pisang ambon terkandung karbohidrat sebanyak 24,0 gr,protein 1,0 gr,energi 92 gr dan lemak $0,3 \mathrm{gr}$.

Media alternatif dari tepung pisang ambon mampu mendukung pertumbuhan jamur. Hal tersebut dikarenakan tepung pisang ambon memiliki kandungan karbohidrat yang tinggi. Pada media pertumbuhan yang mengandung karbohidrat, jamur akan mengekskresikan enzim $\alpha$-amilase untuk mengubah amilum menjadi glukosa, senyawa glukosa tersebut kemudian diserap oleh jamur. Nutrien-nutrien tersebut baru dapat dimanfaatkan sesudah jamur mengekskresikan enzim-enzim ekstraseluler yanrg dapat mengurai senyawa kompleks dari substrat menjadi senyawa-senyawa yang lebih sederhana (Gandjar, 2006).

Media PDA merupakan media pertumbuhan jamur yang terbaik dikarenakan memiliki formulasi yang sederhana dalam mendukung pertumbuhan berbagai jenis jamur sedangkan media konsentrasi terbaik adalah konsebtrasi $20 \%$ karena memiliki nutrisi lebih kompleks.

Pada penelitian ini konsentrasi 10\% pertumbuhan jamur Aspergillus niger yaitu pemeriksaan makroskopis: warna koloni berwarna hitam,bentuk bulat dan diameter pada hari pertama sampai hari kelima yaitu $12 \mathrm{~mm}$, sedangkan pemeriksaan mikroskopis sporanya banyak dan berwarna biru dan bentuknya bulat. Pada konsentrasi 20\% pemeriksaan makroskopis: warna koloni berwarna hitam,bentuk bulat dan diameter pada hari pertama sampai hari kelima yaitu $25 \mathrm{~mm}$, sedangkan pemeriksaan mikroskopis: sporanya banyak dan berwarna biru dan bentuknya bulatss.

Menurut penelitian sebelumnya dapat disimpulkan bahwa Laju pertumbuhan koloni yang paling baik pada jamur Aspergillus niger pada penggunaan tepung singkong sebanyak 4 gr yaitu sebesar $1,2 \mathrm{~cm} / \mathrm{hari}$ dan Jumlah spora Aspergillus niger optimal dihasilkan pada penambahan tepung singkong sebanyak 4 gr yaitu $6,0 \times 108 \mathrm{sel} / \mathrm{mL}$.

Sehingga dalam penelitan ini konsentrasi media alternatif pisang ambon (musa acuminata) yang terbaik untuk pertumbuhan jamur Aspergillus niger yaitu konsentrasi 20\% karena diameter pertumbuhannya lebih cepat dari konsentrasi $10 \%$. Sehingga dapat dikatakan bahwa tepung pisang ambon dapat digunakan sebagai media alternatif untuk pertumbuhan jamur Asspergillus niger. 


\section{Kesimpulan}

Bedasarkan hasil penelitian ini dan pembahasan, maka di dapatkan kesimpulan sebagai berikut : Media alternatif pisang ambon dengan konsentrasi $10 \%$ memiliki pertumbuhan jamur yang tebal pada pemeriksaan makroskopis berwarna hitam, ukuran diameter tertinggi $12 \mathrm{~mm}$ dan bentuknya bulat sedangkan pada pemeriksaan mikroskopis warnanya biru dan berbentuk bulat tebal. Media alternatif pisang ambon dengan konsentrarsi $20 \%$ memiliki pertumbuhan jamur yang sangat tebal pada pemeriksaan makroskopis berwarna hitam, ukuran diameter tertinggi $25 \mathrm{~mm}$ dan bentuknya bulat sedangkan pada pemeriksaan mikroskopis warnanya biru dan berbentuk bulat tebal. Tepung pisang ambon dapat digunakan sebagai media alternatif pertumbuhan jamur Aspergillus niger.

\section{Daftar Pustaka}

Andriyani, W. 2005. Isolasi dan Identifikasi Kapang Aspergillus dari Kopi (Coffe sp) Bubuk. Skripsi. FMIPA UNDIP. Semarang

$\begin{array}{lllllll}\text { Anonim. 2013. } & \text { Fungi. Diakses } & \text { pada } & 26 & \text { November } & \end{array}$ (http://pendidikankarakter.org/biosciencelearning/materi/fungi_2013.pdf.)

Cappuccino, J. G., dan Sherman, N. 2014. Manual Laboratorium Biologi. EGC. Jakarta.

Direktorat Gizi Departemen Kesehatan Indonesia. (2009). Kandungan gizi kentang. Jakarta: Departemen Kesehatan Indonesia

Dwidjoseputro. (1990). Dasar-Dasar Mikrobiologi. Jakarta: Djambatan

Gandjar, I., W. Sjamsuridjal, dan A. Detrasi. "Mikologi Dasar danTerapan”. Yayasan Obor Indonesia. Jakarta, Indonesia, 2006

Hardjo, SS., N. S. Indrasti, B. Tajuddin."Pemanfaatan Limbah Industri Pertanian”. Biokonveksi. Pusat Antar Universitas Pangan dan Gizi. IPB. Bogor, 1989

Kwoseh, C.K., Darko. M. A., and Adubofour , K. 2012. Cassava Starch-Agar Blend as Alternative Gelling Agent For Mycological Culture Media. Bots. J. AgricApplSci, 8 (1): 8-15.

Laily, R. (2010) Olahan Dari Kentang. Yogyakarta: Kanisius

Masnun. (2016). TEKNOLOGI MEMBUAT MEDIA PDA. Jambi: Balai Pelatihan Pertanian

Murwani, S. 2015. Dasar-dasar Mikrobiologi Veteriner. Edisi pertama, Universitas Brawijaya Press (UB Press) Elektrinik Pertama dan terbesar di Indonesia. Malang.

Notoadmodjo, S. (2012) Metodologi Penelitian Kesehatan. Jakarta: Rineka Cipta

Prakash R dan Jha S.N. Basic of The Genus Aspergillus. International journal of Research Botany 4, no. 2 (2014): h. 26-30.

Ravimannan, N.,Arulanantham, R., Pathmanathan, S., and Niranjan, Kularajani. 2014. Alternative Culture Media For Fungal Growth Using Different Formulation Of Protein Sources. Annals of Biological Research, 5(1):36-39

Rahman, Ansori. 1989. Teknologi Fermentasi. PAU Pangan dan Gizi. IPB. Bogor.

Sunarmi, Y. I. dan Saparinto, C.2010. Usaha 6 Jenis Jamur Skala Rumah Tangga. Penebar Swadaya. Jakarta.

Tharmila, S., Jeyaseelan, E.C., and Thavaranjit, A. C. 2011. Preliminary Screening Of Alternative Culture Media For The Growth Of Some Selected Fungi. Archives of Applied Science Research, 3 (3):389-393 